\title{
Characteristics of Sulfobacillus acidophilus sp. nov. and other moderately thermophilic mineral-sulphide-oxidizing bacteria
}

\author{
Paul R. Norris, Darren A. Clark, Jonathan P. Owen and Sara Waterhouse
}

Author for correspondence: Paul R. Norris. Tel: +44 1203 523733. Fax: +44 1203523701.

e-mail: pn@dna.bio.warwick.ac.uk

Department of Biological Sciences, University of Warwick, Coventry

CV4 7AL, UK

\begin{abstract}
Several isolates of Gram-positive, acidophilic, moderately thermophilic, ferrous-iron- and mineral-sulphide-oxidizing bacteria were examined to establish unequivocally the characteristics of Sulfobacillus-like bacteria. Two species were evident: Sulfobacillus thermosulfidooxidans with $48-50 \mathrm{~mol} \%$ G + C and Sulfobacillus acidophilus sp. nov. with 55-57 mol\% G + C. Both species grew autotrophically and mixotrophically on ferrous iron, on elemental sulphur in the presence of yeast extract, and heterotrophically on yeast extract. Autotrophic growth on sulphur was consistently obtained only with S. acidophilus.
\end{abstract}

Keywords: Sulfobacillus, iron oxidation, acidophiles

\section{INTRODUCTION}

Acidophilic bacteria that are most active in oxidation of ferrous iron and mineral sulphides at about $45-50{ }^{\circ} \mathrm{C}$ (Brierley \& Brierley, 1986; Norris, 1990) have been isolated from geothermal environments, mineral sulphide mines, coal and mineral spoil heaps, and commercial metal leaching dumps. Their growth on ferrous iron and mineral sulphides in medium containing yeast extract was described (Brierley \& Le Roux, 1977; Golovacheva \& Karavaiko, 1979) before it was found this supplement could be replaced by separate, defined sources of organic carbon (some amino acids) and reduced sulphur (Brierley et al., 1978; Norris et al., 1980). Autotrophic growth on ferrous iron was demonstrated when culture atmospheres were enriched with $\mathrm{CO}_{2}$ (Marsh \& Norris, 1983a) and was confirmed by measurements of $\mathrm{CO}_{2}$ incorporation (Wood \& Kelly, 1983) and ribulose bisphosphate carboxylase/ oxygenase activity (Wood \& Kelly, 1985). Mineral sulphide dissolution during autotrophic growth of some strains (Marsh \& Norris, 1983b) demonstrated a potential application of these bacteria in extraction of metals from mineral sulphide concentrates and indicated a capacity for significant biogeochemical activity in acidic environments.

One of the most studied strains has been named Sulfobacillus thermosulfidooxidans (Golovacheva \& Karavaiko, 1979). Some variation in its morphology (rods and coryneforms) has been described (Golovacheva, 1979) but this has not been reported for otherwise apparently similar bacteria (Brierley, 1978; Ghauri \& Johnson, 1991).
Isolates from several locations have been examined and are described in this paper in order to establish unequivocally the characteristics of Sulfobacillus-like bacteria. The dissimilarity between the reported $16 \mathrm{~S}$ rDNA sequences of the $S$. thermosulfidooxidans type strain (Tourova et al., 1994) and of very similar bacteria is addressed.

\section{METHODS}

Bacterial strains. The strains examined are listed in Table 1. Sulfobacillus thermosulfidooxidans type strain VKM B-1269 was provided by G. Karavaiko (Institute of Microbiology, RAS, Moscow, Russia) in 1993. Strain TH1 was provided by N. W. Le Roux (then at DTI Warren Spring Laboratory, Stevenage, UK) in 1977. Strains YTF and THW were provided by D. B. Johnson (University of Wales, Bangor). All other strains were isolated in this laboratory. Strains LM1 and BC1 were referred to as strains $\mathrm{LM}$ and $\mathrm{BC}$ in the description of their isolation (Marsh \& Norris, 1983a) and the number added subsequently as different types (e.g. strain LM2, BC13; Norris, 1990) were obtained from the original enrichment cultures or sample sites. Several strains were isolated from provided samples and details of sample site conditions were not available. Strain TH3 was isolated from a copper leaching dump sample that was provided from the New Mexico Institute of Technology, Socorro, by J. A. Brierley (current affiliation Newmont Metallurgical Services, Salt Lake City, UT, USA). It was designated strain TH3 because it appeared very similar (Norris \& Barr, 1985) to another strain TH3 (Brierley, 1978) which was no longer available. Both of these TH3 strains were isolated from the same site. Strain ICP is another isolate of the TH3 type (Clark \& Norris, 1996). Strain C-MT1 (Goebel \& Stackebrandt, 1994) was not examined in this work, but is discussed. It was obtained from a mineral sulphide ore-leaching, continuous bioreactor and described as a 
Table 1. Strains and sources of moderately thermophilic, ferrous-iron-oxidizing bacteria

The approximate date when laboratory cultures were established is indicated.

\begin{tabular}{|ll|}
\hline Strain & \multicolumn{1}{c|}{ Source } \\
\hline S. thermosulfidooxidans & Mineral sulphide ore deposit, Armenia (1977) \\
TH1 & Thermal spring, Iceland (1972) \\
BC1 & Coal spoil heap, Birch Coppice colliery, UK (1981) \\
ALV & Coal spoil heap, near Alvecote, UK (1979) \\
NAL & Coal spoil heap, near Alvecote, UK (1988) \\
LM1 & Thermal spring, Iceland (1981) \\
TH3 & Copper leach dump, New Mexico, USA (1984) \\
2B, 3B, 3C & Thermal spring, Iceland (1989) \\
N & Thermal spring, Yellowstone National Park (1989) \\
YTF & Thermal spring, Yellowstone National Park (1989) \\
THW & Coal spoil heap, Wales (1988) \\
ICP & Thermal spring, Iceland (1993) \\
\hline
\end{tabular}

moderately thermophilic, iron-oxidizing, Gram-positive bacterium.

Culture conditions. All cultures were grown in shaken flasks in a mineral salts medium containing, per litre, $\mathrm{MgSO}_{4} \cdot 7 \mathrm{H}_{2} \mathrm{O}$, $0.5 \mathrm{~g} ;\left(\mathrm{NH}_{4}\right)_{2} \mathrm{SO}_{4}, 0.4 \mathrm{~g} ; \mathrm{K}_{2} \mathrm{HPO}_{4}, 0.2 \mathrm{~g}$; and $\mathrm{KCl}, 0.1 \mathrm{~g}$. When $50 \mathrm{mM}$ ferrous iron was the substrate $\left(\mathrm{FeSO}_{4} .7 \mathrm{H}_{2} \mathrm{O}, 13.9 \mathrm{~g} \mathrm{l}^{-1}\right)$, the medium was initially adjusted with $\mathrm{H}_{2} \mathrm{SO}_{4}$ to $\mathrm{pH} \mathrm{1 \cdot 7.} \mathrm{The}$ medium was supplemented with tetrathionate $\left(\mathrm{K}_{2} \mathrm{~S}_{4} \mathrm{O}_{6}, 0115 \mathrm{~g}\right.$ $\mathrm{1}^{-1}$ ) for autotrophic growth on ferrous iron because some moderately thermophilic, iron-oxidizing acidophiles require a source of reduced sulphur for growth (Brierley et al., 1978; Norris \& Barr, 1985). The medium was adjusted initially to $\mathrm{pH}$ 2 when yeast extract $\left(0 \cdot 25 \mathrm{~g} \mathrm{l}^{-1}\right)$ was the substrate, and to $\mathrm{pH} 3$ when the substrate was elemental sulphur $\left(5 \mathrm{~g} \mathrm{l}^{-1}\right)$. Medium containing sulphur or yeast extract was supplemented with a trace of iron $\left(\mathrm{FeSO}_{4} .7 \mathrm{H}_{2} \mathrm{O}, 10 \mathrm{mg} \mathrm{l}^{-1}\right)$. Medium containing pyrite $(40 \%, \mathrm{w} / \mathrm{v}$, iron; particle size diameter $<75 \mu \mathrm{m})$ was adjusted to $\mathrm{pH} 2$ before inoculation. Pyrite was added in two stages, $1 \%(\mathrm{w} / \mathrm{v})$ at inoculation and $4 \%(\mathrm{w} / \mathrm{v})$ when growth was established. Cultures growing autotrophically on ferrous iron, sulphur or pyrite were gassed with $5 \%(\mathrm{v} / \mathrm{v}) \mathrm{CO}_{2}$ in air. All cultures were grown at $48^{\circ} \mathrm{C}$.

Growth assays. As described previously (Marsh \& Norris, 1983a; Wood \& Kelly, 1983, 1984), growth on ferrous iron was followed by titration of residual substrate using ceric sulphate and phenanthroline/ferrous sulphate as indicator. Pyrite dissolution was followed by measuring iron in supernatants of centrifuged samples by atomic absorption spectrophotometry. Heterotrophic growth on yeast extract was estimated as culture optical density, measured at $440 \mathrm{~nm}$ using $1 \mathrm{~cm}$ light path cells and a Beckman DU-70 spectrophotometer.

Microscopy. Photomicrographs were obtained using a Leitz Dialux 22/22 EB microscope and Vario Orthomat 2 automatic microscope camera. Cells were concentrated by centrifugation from exponentially growing cultures, or from cultures shortly after lag phase if an exponential phase was not obvious, as with some strains growing autotrophically on ferrous iron. A Joel JEM-100S transmission electron microscope was used to view thin sections of cells which had been fixed in glutaraldehyde and stained with uranyl acetate using standard techniques.

Electrophoresis. Cell lysates were prepared by incubation with lysozyme $\left(5 \mathrm{mg} \mathrm{ml}^{-1}\right)$ at $37^{\circ} \mathrm{C}$ for $15 \mathrm{~min}$ and subjected to SDSPAGE (Laemmli, 1970) using a 10\% (w/v) polyacrylamide gel.
DNA extraction and analyses. Cells were grown with yeast extract as substrate, harvested by centrifugation and washed with distilled water. Cell pellets from cultures (10 l) were resuspended in $6 \mathrm{ml}$ buffer $(10 \mathrm{mM}$ Tris/ $\mathrm{HCl}, 1 \mathrm{mM}$ EDTA, $\mathrm{pH}$ 8). EDTA $(0.25 \mathrm{M}, \mathrm{pH} 8,3.75 \mathrm{ml})$ and $50 \mathrm{mg}$ lysozyme were added. After incubation at $37^{\circ} \mathrm{C}$ for $15 \mathrm{~min}, 125 \mu \mathrm{l}$ proteinase $\mathrm{K}\left(20 \mathrm{mg} \mathrm{ml}^{-1}\right)$ and $3.25 \mathrm{ml} \mathrm{SDS}(10 \% \mathrm{w} / \mathrm{v})$ were added and incubation continued until the suspension cleared. DNA was isolated and purified following a modification of the Marmur protocol (Johnson, 1991) and a $\mathrm{CsCl}$ centrifugation step before dialysis.

DNA from moderate thermophiles and DNA (Sigma) from Clostridium perfringens $(26.5 \mathrm{~mol} \% \mathrm{G}+\mathrm{C})$, Escherichia coli $(52 \mathrm{~mol} \% \mathrm{G}+\mathrm{C})$ and Micrococcus luteus $(72 \mathrm{~mol} \% \mathrm{G}+\mathrm{C})$ was dialysed three times against diluted standard saline citrate (i.e. $15 \mathrm{mM} \mathrm{NaCl}, 1.5 \mathrm{mM}$ trisodium citrate, $\mathrm{pH} 7$ ). Melting curve mid-points $\left(T_{m}\right)$ were determined using a Hewlett Packard automated DNA melt testing system and 8452A spectrophotometer. Unknown base compositions were calculated from the formula $\mathrm{mol} \% \mathrm{G}+\mathrm{C}=\mathrm{mol} \% \mathrm{G}+\mathrm{C}$ of $X+2 \cdot 08\left(T_{\mathrm{m}}-T_{\mathrm{m}}\right.$ of $X$ ), where $X$ was the DNA of known base composition (Owen \& Hill, 1979). Means of duplicate $T_{m}$ determinations were used in the calculations and the mol $\% \mathrm{G}+\mathrm{C}$ of each moderate thermophile was taken as the mean of the three values calculated with reference to values obtained for the three DNA standards.

DNA:DNA hybridization was carried out using a filter hybridization technique as described by Sharp \& Williams (1988). The results are the means of duplicate hybridizations except for strain TH3, with which a single experiment was performed. Hybridization is expressed as percentage of homologous hybridization counts.

Analysis of 165 rDNA sequences. PCR products comprising $16 \mathrm{~S} \mathrm{rDNA}$ of strain $\mathrm{BC} 1$ and $S$. thermosulfidooxidans were generated using $27 \mathrm{f}$ and $1492 \mathrm{r}$ primers (Lane, 1991). Cloning was done using the TA Cloning Kit (Invitrogen). Sequencing was done using primer 357f (Lane, 1991), the downstream vector primer M13r (5'-CAGGAAACAGCTATGAC-3') and an upstream vector primer (5'-GGCCCTCTAGATGCAT-3'). An Applied Biosystems model 373A was used for automatic sequencing. Percentage similarities were calculated for aligned sequences between bases $28-260,371-617$ and $1200-1460$ ( $E$. coli sequence numbering), a total of 741 bases. Included in 
alignments were sequences previously determined by Lane $e t$ al. (1992) for strain BC1 (GenBank accession numbers M79380, M79381 and M79382) and strain ALV (M79375, M79376 and M80290), by Tourova et al. (1994) for S. thermosulfidooxidans (Z21979), and by Goebel \& Stackebrandt (1994) for strain CMT1 (X75270).

\section{RESULTS}

\section{Whole-cell protein electrophoresis profiles}

Comparative electrophoresis of whole-cell proteins of several isolates of ferrous iron-oxidizing moderate thermophiles revealed three groups of strains (Fig. 1). Further comparisons have shown that the protein profile of strain

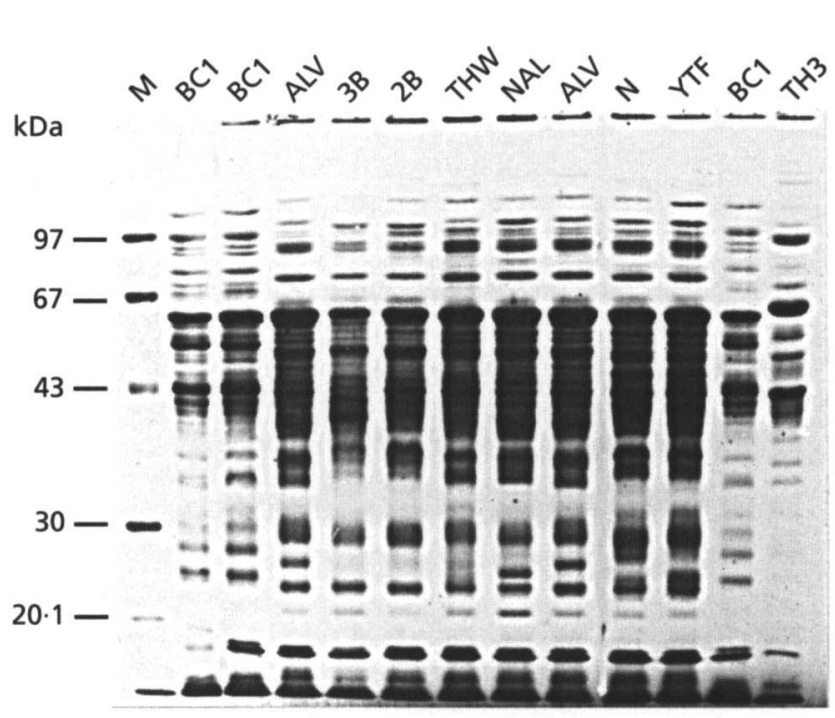

Fig. 1. SDS-PAGE whole-cell protein profiles of strains of moderately thermophilic acidophiles. All cultures were grown on ferrous iron in the presence of yeast extract. Molecular mass markers are in lane $M$.
BC1 matched those of Sulfobacillus thermosulfidooxidans and strains TH1, LM1 and 3C (data not shown). Profiles of most of the other isolates (strains ALV, NAL, 2B, 3B, THW, YTF and N) did not match that of strain BC1 (Fig. 1) and were also different therefore from other representatives of the group containing $S$. thermosulfidooxidans. Within the strain ALV group, protein profiles were similar. There were a few, reproducible differences, particularly in the region showing polypeptides of about $25 \mathrm{kDa}$ apparent molecular mass, where major bands were not aligned in the protein profiles of strains ALV and NAL, and were absent from profiles of strains THW, $2 \mathrm{~B}$ and $3 \mathrm{~B}$. The SDS-PAGE protein profile of strain $\mathrm{TH} 3$ was very different from those of strain $\mathrm{BC} 1$ and strain ALV group bacteria (Fig. 1).

\section{DNA:DNA hybridization}

Three groups of moderate thermophiles were evident among the strains examined (Table 2), confirming the divisions seen with the protein profiles. Only one species in each group was indicated. There was generally well over $70 \%$ DNA:DNA hybridization among isolates of the strain ALV group. Further experiments with DNA from strains NAL, 2B, THW and 3B (not performed in duplicate; data not shown) showed high levels of DNA:DNA hybridization among these strains, so the latter two can also be included in the single species of the strain ALV group. There was over $80 \%$ hybridization between DNA from strain $\mathrm{BC} 1$ and $S$. thermosulfidooxidans.

\section{DNA G + C content}

The range of $\mathrm{G}+\mathrm{C} \mathrm{mol} \%$ values for $S$. thermosulfidooxidans (Table 3) could reflect the variety of subspecies as well as different procedures in laboratories. The value obtained for the type strain in this study, and all values given for the similar strains $\mathrm{BC} 1$ and $\mathrm{TH} 1$ (Table 3 ), indicated a $\mathrm{G}+\mathrm{C}$ content of between 48 and $50 \mathrm{~mol} \%$

Table 2. DNA: DNA relatedness among moderately thermophilic, ferrous-iron-oxidizing acidophiles

Results are expressed as percentages of the homologous hybridizations. ND, Not determined.

\begin{tabular}{|lrrrrrrrrr|}
\hline Filter-bound & \multicolumn{7}{|c|}{${ }^{3}$ H-labelled DNA from: } \\
\cline { 2 - 8 } DNA from: & S. $\boldsymbol{t}$ th.* & BC1 & ALV & NAL & 2B & 3B & N & TH3 \\
\hline S. th. $^{*}$ & 100 & 81 & ND & 11 & ND & ND & ND & 2 \\
BC1 & 90 & 100 & 8 & 11 & 7 & 8 & 8 & 4 \\
ALV & ND & 13 & 100 & 93 & 88 & 69 & 83 & ND \\
NAL & 12 & 10 & 86 & 100 & 93 & 83 & 79 & 5 \\
2B & ND & 10 & 82 & 96 & 100 & 96 & 83 & ND \\
3B & ND & 14 & 81 & 92 & 95 & 100 & 94 & ND \\
N & ND & 13 & 75 & 82 & 73 & 83 & 100 & ND \\
TH3 & 3 & 4 & ND & 2 & ND & ND & ND & 100 \\
\hline
\end{tabular}

* S. thermosulfidooxidans. 
Table 3. Chromosomal DNA base composition of moderately thermophilic, ferrous-iron-oxidizing acidophiles

\begin{tabular}{|lll|}
\hline & \multicolumn{2}{c|}{ mol \% G+C } \\
\cline { 2 - 3 } & This study & \multicolumn{1}{c|}{ Other valuest } \\
\hline S.th.* & $48 \cdot 4$ & $53 \cdot 6^{a}, 47 \cdot 2^{b}, 49 \cdot 3^{c}, 45 \cdot 5^{d}$ \\
BC1 & $48 \cdot 6$ & $50 \cdot 4^{e}, 48 \cdot 2^{f}$ \\
TH1 & ND & $48^{g}, 49 \cdot 7^{e}, 48^{h}$ \\
ALV & $55 \cdot 3$ & $57 \cdot 0^{e}$ \\
NAL & $56 \cdot 2$ & $54 \cdot 9^{f}$ \\
N & $55 \cdot 1$ & \\
TH3 & $67 \cdot 7$ & $68 \cdot 5^{e}, 68 \cdot 0^{f}$ \\
\hline
\end{tabular}

ND, Not determined.

* S. thermosulfidooxidans.

† a, Golovacheva \& Karavaiko (1979); b, Karavaiko et al. (1988); c, subspecies thermotolerans, Kovalenko \& Malakhova (1984); d, subspecies asporogenes, Vartanyan et al.(1988); $e$, Harrison (1986); $f$, Clark \& Norris (1996); $g$, Brierley et al. (1978); $b$, Ghauri \& Johnson (1991).

for S. thermosulfidooxidans. The $\mathrm{G}+\mathrm{C}$ content range of the strain ALV group bacteria (ALV, NAL and N) was $55-57 \mathrm{~mol} \%$ (Table 3). A value of approximately $68 \mathrm{~mol} \% \mathrm{G}+\mathrm{C}$ has been consistently obtained for the unrelated strain TH3.

\section{5 rDNA analysis}

The partial 16S rDNA sequence of strain BC1 determined in this work had an overall similarity of $99.5 \%$ with the sequence of the same strain previously determined by Lane et al. (1992). Comparison of the strain BC1 sequence (obtained in this work) with the aligned sequences from $S$. thermosulfidooxidans (obtained in this work) and strain CMT1 (database sequence) showed similarities of $97.3 \%$ and $97.6 \%$, respectively. The similarity between the sequence of strain BC1 (obtained in this work) and the $S$. thermosulfidooxidans database sequence (Tourova et al., 1994) was $73 \%$. The similarity between the partial sequences of strain BC1 and strain ALV was $88.6 \%$.

\section{Morphology}

Strains of the three groups of moderate thermophiles defined by whole-cell protein electrophoresis, DNA $\mathrm{G}+\mathrm{C}$ content and DNA:DNA hybridization could be similarly grouped on the basis of their size and their morphological variation in response to growth conditions. Strain ALV was in part an exception to the pattern, growing as chains of sometimes distorted cells when oxidizing ferrous iron (Fig. 2c), but reverting to regular rods during autotrophic growth on sulphur (not shown) and during heterotrophic growth on yeast extract. Other isolates of the strain ALV group varied little in form $(0.5-0.8 \times 3-5 \mu \mathrm{m})$. In contrast, $S$. thermosulfidooxidans strains tended to increase in size from about $0.6 \times 2-3.5 \mu \mathrm{m}$ during autotrophic growth on ferrous iron to $0.8-1.8 \times 3-6.5 \mu \mathrm{m}$ during growth on ferrous iron plus yeast extract and heterotrophic growth with yeast extract as the sole substrate (Fig. 2). The length of individual cells observed by light microscopy was difficult to measure, with most of the longer forms, including the filamentous forms of strain ALV, comprising dividing cells which had not separated (electron microscopy observations, not shown). With yeast extract as sole substrate, some $S$. thermosulfidooxidans strains became shorter and swollen, particularly strain BC1 (Fig. 2b) and, as reported previously, strain TH1 (Norris et al., 1980). Although flagella were not observed with the cells prepared for microscopy, limited motility of most Sulfobacillus-like strains was evident, but only when they were growing autotrophically on ferrous iron.

As described previously (Brierley, 1978), strain TH3 was morphologically unique among the isolates. The cells were characteristically narrower $(0.4 \mu \mathrm{m}$ wide) than Sulfobacillus strains and often in filaments (Fig. 2f). However, strain TH3 was occasionally observed to grow as pairs of relatively short cells, particularly during exponential growth on yeast extract in well-agitated cultures, when the cells were also motile.

\section{Endospore formation}

Endospores were observed in S. thermosulfidooxidans and in the strain ALV group bacteria. They were more commonly observed in cells under the relatively poor nutritional conditions of autotrophic growth on ferrous iron (Fig. 2), with only strain $\mathrm{N}$ also showing endospores during heterotrophic growth (Fig. 2e). Whether sporulation is more prevalent towards the stationary phase of growth in the presence of yeast extract has not been examined. Spores appeared mostly spherical and terminal in the strain ALV group bacteria and possibly slightly more oval with less swelling of the cell in the $S$. thermosulfidooxidans strains. Sections of sporulating cells of each type revealed a typical Bacillus forespore development and mature spore structure, with clearly visible cortex and spore coat layers (Fig. 3).

\section{Growth and ferrous iron oxidation}

The three groups of moderate thermophiles had different capacities for autotrophic growth on ferrous iron, assuming that iron oxidation was directly related to growth. Ferrous iron oxidation by strain TH1 growing on ferrous iron and yeast extract has previously been correlated with growth (cell carbon and protein) (Marsh \& Norris, 1983a). Iron oxidation by autotrophically growing strains $\mathrm{BC} 1$ and $\mathrm{ALV}$ has been correlated with $\mathrm{CO}_{2}$ fixation (Wood \& Kelly, 1983). S. thermosulfidooxidans isolates (e.g. the type strain and strain LM1; Fig. 4) were able to maintain an initially high rate of oxidation of $50 \mathrm{mM}$ ferrous iron. A gradual decline in the rate of oxidation was more evident with strains ALV and NAL and there was virtually no exponential phase of iron oxidation during 
growth of strains TH3 and ICP. In the presence of yeast extract, strains of all three groups oxidized $50 \mathrm{mM}$ ferrous iron rapidly and completely (data not shown), as shown previously with strains BC1, ALV and TH3 (Norris \& Barr, 1985).

\section{Growth and sulphur oxidation}

Growth of all isolates in the presence of yeast extract and sulphur resulted in acidification of the medium, though this was relatively weak in cultures of strains $\mathrm{TH} 3$ and ICP. Transfer through many serial cultures in medium containing sulphur but no yeast extract resulted in consistent, autotrophic growth of strains ALV, NAL, THW, $\mathrm{N}$ and YTF, with, typically, $\mathrm{pH} 1.5$ being reached, as seen previously with strain ALV (Norris et al., 1986). Only strain $2 \mathrm{~B}$ of the strain ALV type did not readily switch to autotrophic growth on sulphur. In contrast, growth of $S$. thermosulfidooxidans, strain BC1 and strain TH3 became progressively weaker through serial culture on sulphur in the absence of yeast extract, and autotrophic cultures could not be maintained.

\section{Growth on pyrite}

Growth of some bacteria on mineral sulphides is inhibited by agitation with high mineral concentrations unless cultures are allowed to become established under less severe conditions (unpublished results). Strains BC1 and $\mathrm{N}$, and the pyrite enrichment culture from which strain $\mathrm{N}$ was isolated, were therefore grown with only $1 \%(\mathrm{w} / \mathrm{v})$ pyrite initially (Fig. 5). The concentration of pyrite was then increased so that concentrations of potentially growth-inhibiting end products of pyrite oxidation, $\mathrm{H}_{2} \mathrm{SO}_{4}$ and ferric iron, were reached. Extensive pyrite dissolution occurred during autotrophic growth of all Sulfobacillus-like isolates tested ( $S$. thermosulfidooxidans, strains BC1, LM1, N, NAL, THW, YTF) except strain ALV. After addition of $4 \%(\mathrm{w} / \mathrm{v})$ pyrite to established cultures (Fig. 5), iron solubilization was more rapid by strain BC1 $\left(60 \mathrm{mg} \mathrm{l}^{-1} \mathrm{~h}^{-1}\right)$ than by strain $\mathrm{N}\left(41 \mathrm{mg} \mathrm{l}^{-1}\right.$ $\left.h^{-1}\right)$.

\section{Heterotrophic growth}

Bacteria of the strain ALV group generally tended to grow more readily than $S$. thermosulfidooxidans strains when switched from autotrophic growth and they were also easier to maintain subsequently with yeast extract as the sole substrate. The mean doubling times (estimated from culture optical density increase) were between 6 and $8 \mathrm{~h}$ for the strain ALV group (strains ALV, NAL, 2B and $\mathrm{N})$ and between 8 and $12 \mathrm{~h}$ for the $S$. thermosulfidooxidans strains (i.e. the type strain, strains BC1, 3C and LM1). The yields of strains of both groups (estimated from culture optical density) were approximately proportional to the yeast extract concentration between $0.1 \mathrm{~g} \mathrm{l}^{-1}$ and $0.5 \mathrm{~g} \mathrm{l}^{-1}$. However, the maximum yield of $S$. thermosulfidooxidans strains growing on yeast extract $\left(0.25 \mathrm{~g} \mathrm{l}^{-1}\right)$ was on average one-third less $\left(\mathrm{OD}_{440} 0 \cdot 15-0 \cdot 2\right)$ than that of strain ALV group bacteria $\left(\mathrm{OD}_{440} 0 \cdot 3\right)$. The optimum $\mathrm{pH}$ for growth of most strains on yeast extract was $2-2 \cdot 2$, but the precise optima were not determined. The growth rate and yield of strain TH1 were considerably reduced at $\mathrm{pH} 1.5$ and $\mathrm{pH} 3.0$ in comparison to growth at $\mathrm{pH} 2$ (data not shown). In contrast, acidophilic, moderately thermophilic, heterotrophic Bacillus- or Alicyclobacillus-like isolates from the same environments as some of the ironoxidizing bacteria generally grew with estimated doubling times of $1.5-2 \mathrm{~h}$ and with a higher optimum $\mathrm{pH}$ (P. R. Norris, unpublished results).

\section{DISCUSSION}

The Sulfobacillus-like bacteria examined were clearly divided into two groups on a range of criteria (protein profiles, $\mathrm{G}+\mathrm{C}$ content, DNA :DNA hybridization, morphology, characteristics of autotrophic growth on ferrous iron and sulphur, and heterotrophic growth yield). Taking into account all of these features, the extreme similarity of isolates in the first group, with $48-50 \mathrm{~mol} \%$ $G+C$, indicated that they belonged to a single species. It is proposed that this should be Sulfobacillus thermosulfidooxidans, notwithstanding the incompatible rDNA sequences of the type strain as given in the database and as determined in this work. A phylogenetic tree derived from database sequences has placed $S$. thermosulfidooxidans in a cluster with the acidophilic heterotroph Alicyclobacillus rather than with strains BC1 and ALV (Tourova et al., 1994), with which it appears to have much more in common. Subspecies of $S$. thermosulfidooxidans have been described as thermotolerans (Kovalenko \& Malakova, 1984) and asporogenes (Vartanyan et al., 1988). The relatively low mol \% G $+\mathrm{C}$ contents of these strains (Table 3) places them with $S$. thermosulfidooxidans rather than the strain ALV group of bacteria. The $81 \%$ DNA:DNA hybridization between sub-species asporogenes and $S$. thermosulfidooxidans confirms this placement (Vartanyan et al., 1988).

It is proposed that the second group of Sulfobacillus-like bacteria, with 55-57 mol\% G+C, represent a new species, Sulfobacillus acidophilus. The two species shared little DNA:DNA relatedness but strain BC1 (S. thermosulfidooxidans) and strain ALV (S. acidophilus) are more closely related phylogentically to each other than to any other species (Lane et al., 1992) and they share a similar general physiology. Similar difference spectra indicated principally $b$-type and $a a_{3}$ cytochromes in strain TH1 ( $S$. thermosulfidooxidans) and strain ALV (S.acidophilus) (Barr et al., 1990). The mixotrophic behaviour of strains ALV and BC1 was also generally similar, with simultaneous utilization of glucose and $\mathrm{CO}_{2}$ during growth on ferrous iron (Wood \& Kelly, 1983), although yeast extract depressed $\mathrm{CO}_{2}$ fixation by strain $\mathrm{BC} 1$ more than that by strain $\mathrm{ALV}$ and, during growth in the absence of an enhanced $\mathrm{CO}_{2}$ concentration, glucose stimulation of ferrous iron oxidation by strain ALV was stronger than with strain BC1. The difference in stimulation by glucose under air was also seen with strains NAL ( $S$. acidophilus) and LM1 ( $S$. thermosulfidooxidans), the latter showing much less improvement in growth (Clark \& Norris, 1996). Glucose was utilized primarily by the oxidative pentose phosphate pathway in strain ALV (Wood \& Kelly, 1984). Strain 
(a)
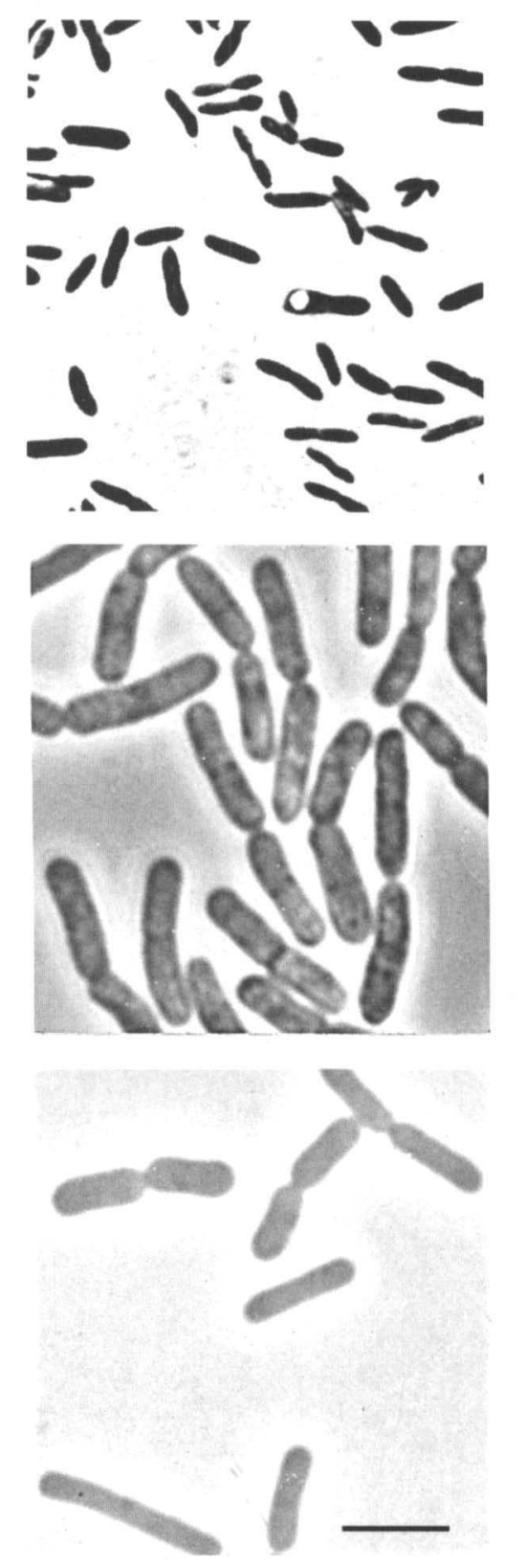

(b)
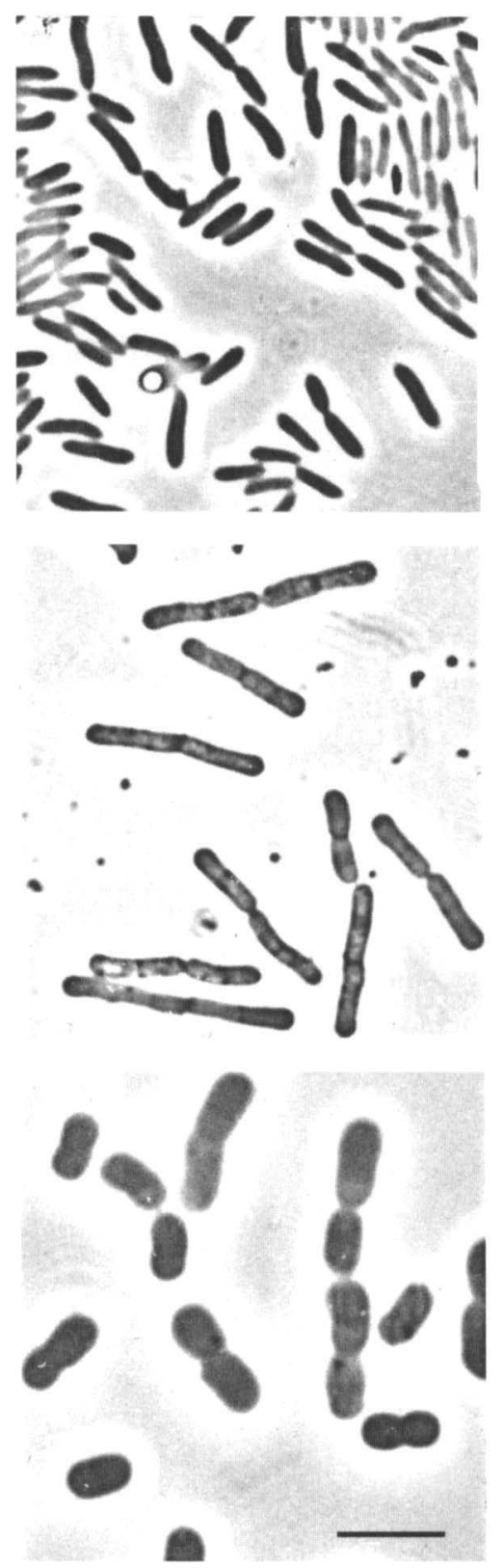

(c)
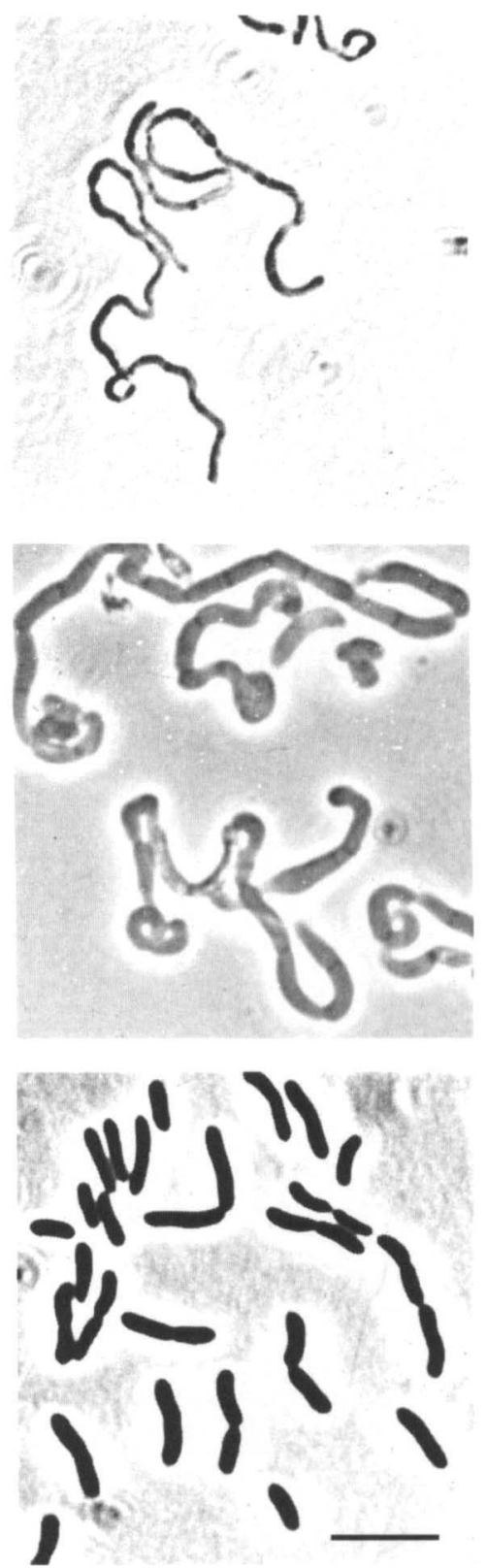

Fig. 2. For legend see facing page.

ALV has received most study (Marsh \& Norris, 1983b; Wood \& Kelly, 1983, 1984; Norris et al., 1986; Harrison, 1986), but this comparison of several isolates has shown that its morphology during growth on iron and its poor growth on pyrite were not typical of the species. Strain NAL, isolated from the same site as strain ALV, is proposed as the type strain.

Several S. acidophilus strains catalysed extensive and rapid dissolution of pyrite, though with strain $\mathrm{N}$ at least, the rate was still slower than with an $S$. thermosulfidooxidans strain (Fig. 5). There was also a tendency for the rate to decline more rapidly as the acidity and the ferric iron concentration increased during the mineral dissolution (Fig. 5). A difference in susceptibility of the two Sulfobacillus species to ferric iron end-product inhibition of ferrous iron oxidation was also indicated by the more rapidly declining oxidation rate during growth of $S$. acidopbilus (Fig. 4). Much greater inhibition of strain $A L V$, in comparison to strain $\mathrm{BC} 1$, occurred when ferric iron was added to growth medium (Norris et al., 1988). The least extensive ferrous iron oxidation was seen during growth of strains TH3 and ICP (Fig. 4), and this has also been correlated with an increased sensitivity to ferric iron 
(d)
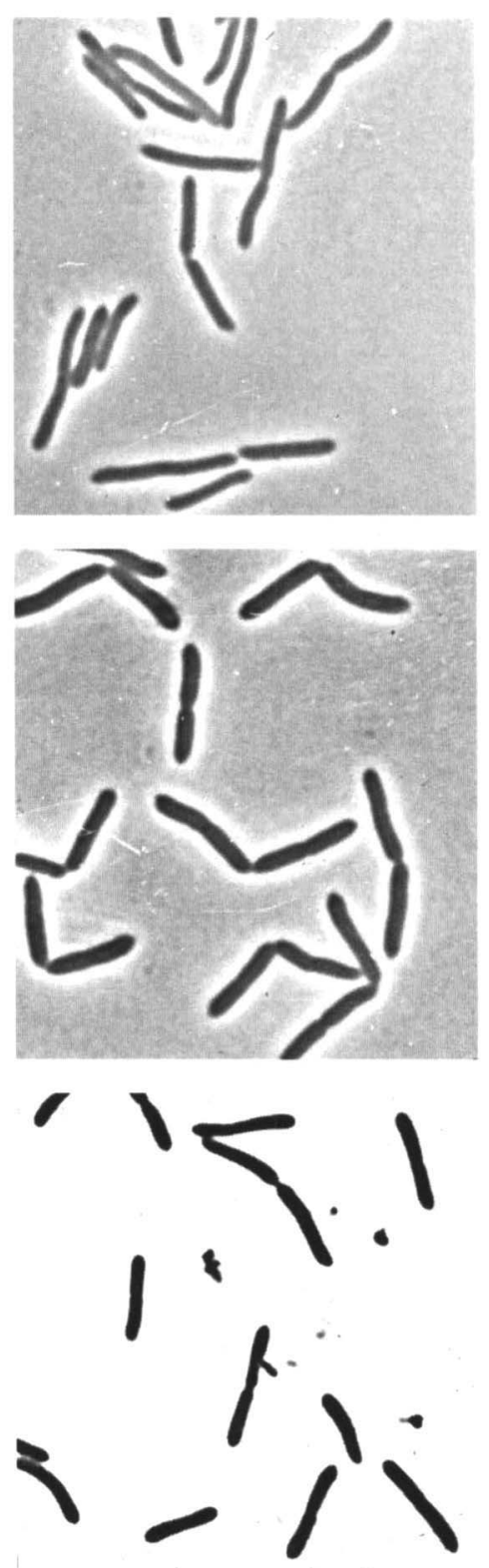

(e)
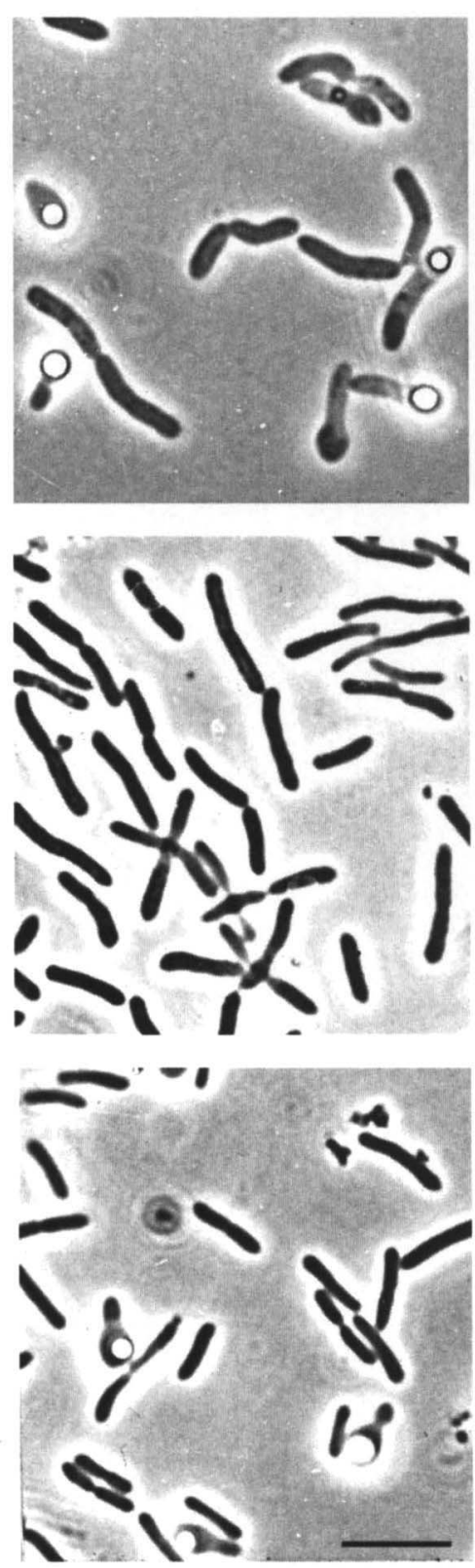

(f)
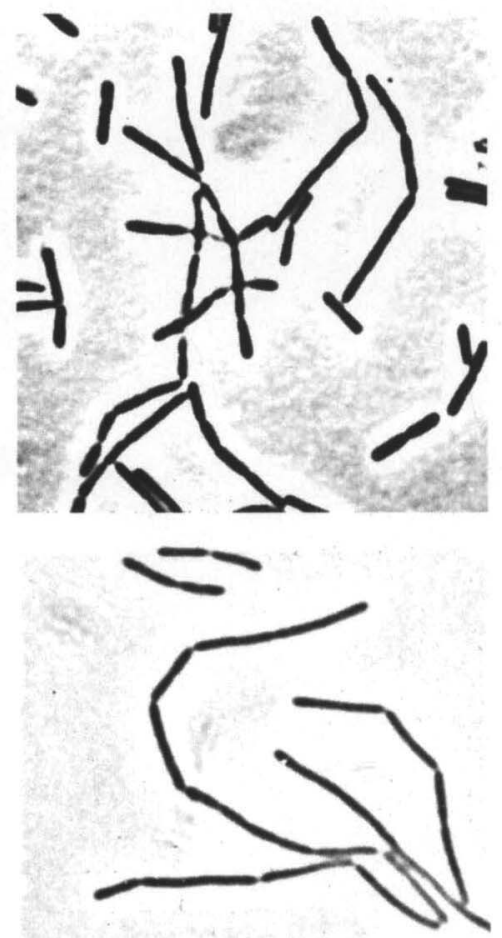

I

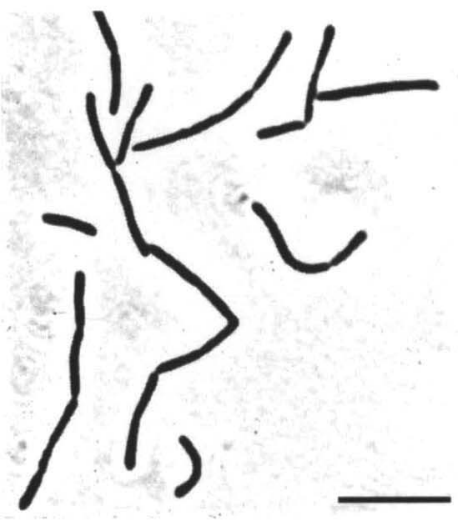

Fig. 2. Moderately thermophilic, acidophilic bacteria observed by light microscopy. Growth was on ferrous iron autotrophically (top row), on ferrous iron plus yeast extract (middle row), or heterotrophically on yeast extract (bottom row). All to same scale; bars $5 \mu \mathrm{m}$. Column (a) S. thermosulfidooxidans, (b) strain BC1, (c) strain ALV, (d) strain NAL, (e) strain $\mathrm{N},(\mathrm{f})$ strain $\mathrm{TH}$.

in comparison with that of $S$. thermosulfidooxidans strains (D. A. Clark \& P. R. Norris, unpublished).

Strain TH3 was clearly not related to the Sulfobacillus species. A new genus has been proposed, Acidimicrobium, with strain TH3 and strain ICP as isolates of its single species, A. ferrooxidans (Clark \& Norris, 1996). Moderately thermophilic, ferrous-iron-oxidizing bacteria that appear distinct from Sulfobacillus and Acidimicrobium species have also been isolated (e.g. strain LM2: Norris,
1990; Ghauri \& Johnson, 1991) but remain to be fully characterized.

\section{Description of Sulfobacillus acidophilus sp. nov.}

Sulfobacillus acidophilus (a.ci.do'phi.lus) sp. nov. ML n. acidum an acid; Gr. adj. philus loving; ML adj. acidophilus acid-loving.

Gram-positive rods $(0.5-0.8 \times 3.0-5.0 \mu \mathrm{m})$ with spherical endospores. Optimum growth is at $45-50^{\circ} \mathrm{C}$ and approxi- 

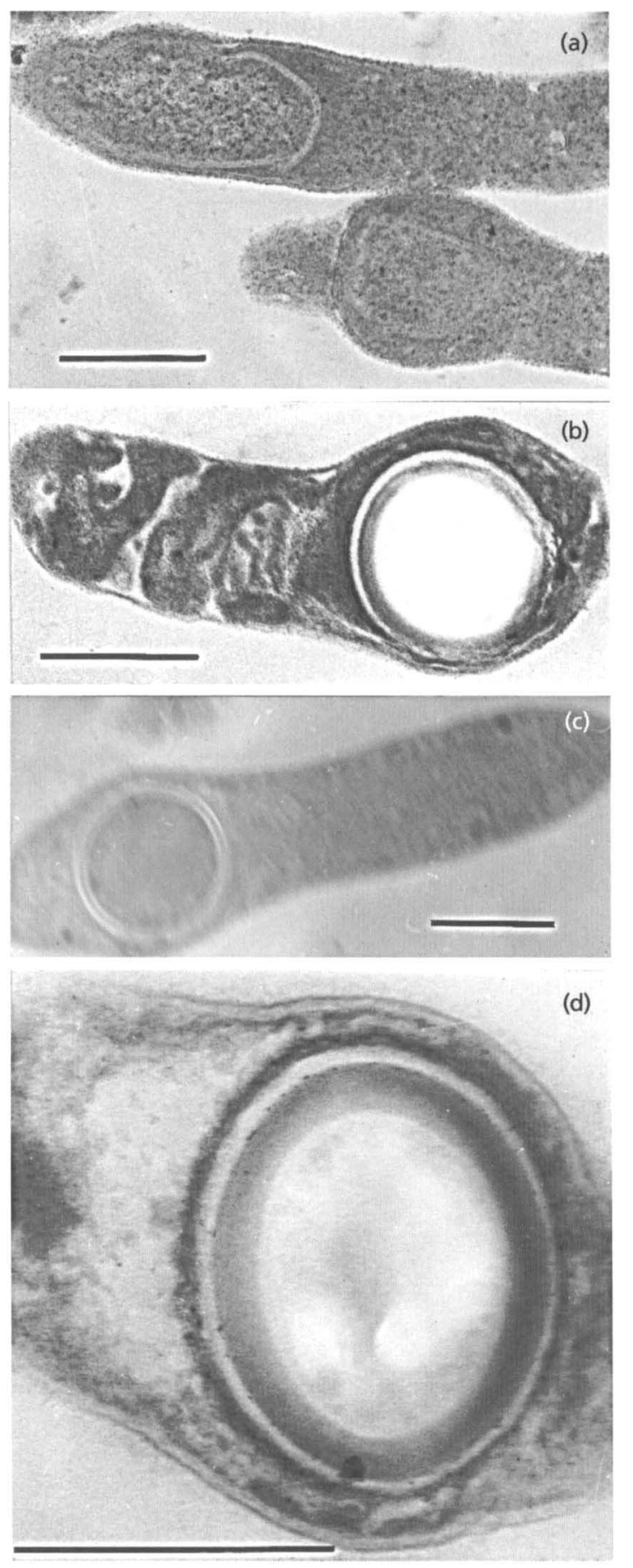

Fig. 3. Endospore formation in strain NAL $(a, b)$ and strain $B C 1$ (c, d). Bacteria were grown autotrophically on ferrous iron. Bars, $0.5 \mu \mathrm{m}$.

mately $\mathrm{pH} 2$. Autotrophic growth occurs with ferrous iron and elemental sulphur as substrates. Growth on ferrous iron can also be mixotrophic with simultaneous utilization of glucose and $\mathrm{CO}_{2}$. Heterotrophic growth occurs with yeast extract as substrate. Chromosomal DNA base composition is between 55 and $57 \mathrm{~mol} \%$

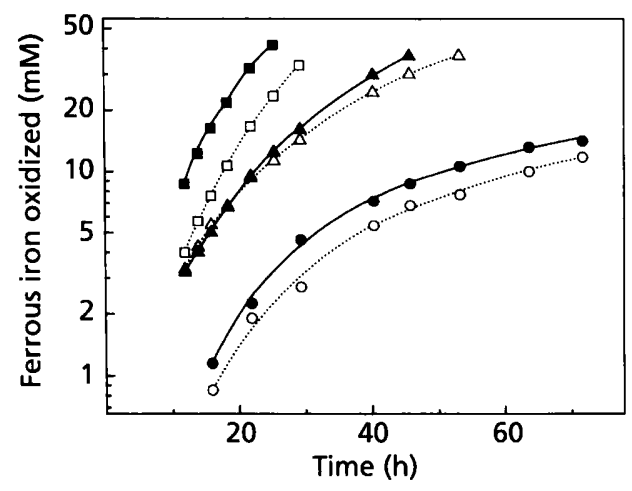

Fig. 4. Ferrous iron oxidation during autotrophic growth of acidophiles at $48^{\circ} \mathrm{C}$. $\square$, S. thermosulfidooxidans; $\square$, strain LM1; $\Delta$, strain ALV; $\triangle$, strain NAL; $O$, strain ICP; $O$, strain TH3.

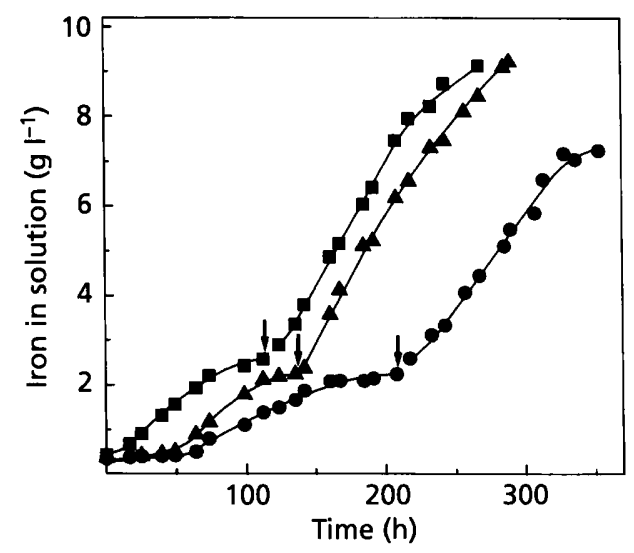

Fig. 5. Dissolution of pyrite at $48{ }^{\circ} \mathrm{C}$ during growth of strain BC1 ( $\square$ ), strain $N(O)$ and a mixed enrichment culture from which strain $\mathbf{N}$ was isolated $(\boldsymbol{\Delta})$. The concentration of pyrite, initially $1 \%(w / v)$, was increased with addition (arrowed) of $4 \%$ $(w / v)$ mineral to each culture.

$\mathrm{G}+\mathrm{C}$. Source: various acidic environments rich in iron, sulphur or mineral sulphides. Type strain: strain NAI (German Collection of Micro-organisms, DSM 10332).

\section{ACKNOWLEDGEMENTS}

This work was supported by a grant and a CASE studentship (D. A.C. with Shell Research Ltd, Sittingbourne) from the SERC Biotechnology Directorate, and by a grant from the NERC. We are particularly grateful to all those noted as supplying cultures and to Dr R. A.D. Williams (Queen Mary and Westfield College, London) for guidance on the DNA hybridization protocol.

\section{References}

Barr, D. W., Ingledew, W. J. \& Norris, P. R. (1990). Respiratory chain components of iron-oxidizing, acidophilic bacteria. FEMS Microbiol Lett 70, 85-90.

Brierley, J. A. (1978). Thermophilic iron-oxidizing bacteria found in copper leaching dumps. Appl Environ Microbiol 36, 523-525. 
Brierley, J. A. \& Brierley, C. L. (1986). Microbial mining using thermophilic microorganisms. In Thermophiles: General, Molecular and Applied Microbiology, pp. 279-305. Edited by T. D. Brock. New York: Wiley.

Brierley, J. A. \& Le Roux, N. W. (1977). A facultative Thiobacilluslike bacterium: oxidation of iron and pyrite. In GBF Conference: Bacterial Leacbing, pp. 55-66. Edited by W. Schwartz. New York: Verlag Chemie.

Brierley, J. A., Norris, P. R., Kelly, D. P. \& Le Roux, N. W. (1978). Characteristics of a moderately thermophilic and acidophilic ironoxidizing Tbiobacillus. Eur J Appl Microbiol 5, 291-299.

Clark, D. A. \& Norris, P. R. (1996). Acidimicrobium ferrooxidans gen. nov., sp. nov.: mixed-culture ferrous iron oxidation with Sulfobacillus species. Microbiology 142, 785-790.

Ghauri, M. A. \& Johnson, D. B. (1991). Physiological diversity amongst some moderately thermophilic iron-oxidising bacteria. FEMS Microbiol Ecol 85, 327-334.

Goebel, B. M. \& Stackebrandt, E. (1994). Cultural and phylogenetic analysis of mixed microbial populations found in natural and commercial bioleaching environments. Appl Environ Microbiol 60, 1614-1621.

Golovacheva, R. S. (1979). Characteristics of Sulfobacillus thermosulfidooxidans morphogenesis. Microbiology (English translation of Mikrobiologiya) 48, 705-709.

Golovacheva, R. S. \& Karavaiko, G. I. (1979). Sulfobacillus - a new genus of spore-forming thermophilic bacteria. Microbiology (English translation of Mikrobiologiya) 48, 658-665.

Harrison, A. P., Jr. (1986). Characteristics of Thiobacillus ferrooxidans and other iron-oxidizing species, with emphasis on nucleic acid analyses. Biotechnol Appl Biochem 8, 249-257.

Johnson, J. L. (1991). Isolation and purification of nucleic acids. In Nucleic Acid Techniques in Bacterial Systematics, pp. 1-19. Edited by E. Stackebrandt \& M. Goodfellow. Chichester: Wiley.

Karavaiko, G. I., Golovacheva, R. S., Pivovarova, T. A., Tzaplina, I. A. \& Vartanyan, N. S. (1988). Thermophilic bacteria of the genus Sulfobacillus. In Biobydrometallurgy, Proceedings of the International Symposium, pp. 29-41. Edited by P. R. Norris \& D. P. Kelly. Kew: Science and Technology Letters.

Kovalenko, E. V. \& Malakova, P. T. (1984). The spore-forming iron-oxidizing bacterium Sulfobacillus thermosulfidooxidans. Microbiology (English translation of Mikrobiologiya) 52, 760-763.

Laemmli, U. K. (1970). Cleavage of structural proteins during the assembly of the head of bacteriophage T4. Nature 227, 680-685.

Lane, D. J. (1991). 16S/23S rRNA sequencing. In Nucleic Acid Techniques in Bacterial Systematics, pp. 115-175. Edited by E. Stackebrandt \& M. Goodfellow. Chichester: Wiley.

Lane, D. J., Harrison, A. P., Jr, Stahl, D., Pace, B., Giovannoni, S. J., Olsen, G. J. \& Pace, N. R. (1992). Evolutionary relationships among sulfur- and iron-oxidizing eubacteria. J Bacteriol 174, 269-278.

Marsh, R. M. \& Norris, P. R. (1983a). The isolation of some thermophilic, autotrophic iron- and sulphur-oxidizing bacteria. FEMS Microbiol Lett 17, 311-315.
Marsh, R. M. \& Norris, P. R. (1983b). Mineral sulphide oxidation by moderately thermophilic acidophilic bacteria. Biotechnol Lett $\mathbf{5}$, 585-590.

Norris, P. R. (1990). Acidophilic bacteria and their activity in mineral sulfide oxidation. In Microbial Mineral Recovery, pp. 3-27. Edited by H. L. Ehrlich \& C. L. Brierley. New York: McGrawHill.

Norris, P. R. \& Barr, D. W. (1985). Growth and iron oxidation by acidophilic moderate thermophiles. FEMS Microbiol Lett 28, 221-224.

Norris, P. R., Brierley, J. A. \& Kelly, D. P. (1980). Physiological characteristics of two facultatively thermophilic mineral-oxidising bacteria. FEMS Microbiol Lett 7, 119-122.

Norris, P. R., Marsh, R. M. \& Lindström, E. B. (1986). Growth of mesophilic and thermophilic acidophilic bacteria on sulfur and tetrathionate. Biotechnol Appl Biochem 8, 318-329.

Norris, P. R., Barr., D. W. \& Hinson, D. (1988). Iron and mineral oxidation by acidophilic bacteria: affinities for iron and attachment to pyrite. In Biobydrometallurgy, Proceedings of the International Symposium, pp. 43-59. Edited by P. R. Norris \& D. P. Kelly. Kew: Science and Technology Letters.

Owen, R. J. \& Hill, L. R. (1979). The estimation of base compositions, base pairing and genome sizes of bacterial deoxyribonucleic acids. In Identification Methods for Microbiologists (SAB Technical Series no. 14), pp. 277-296. Edited by F. A. Skinner \& D. W. Lovelock. London: Academic Press.

Sharp, R. J. \& Williams, R. A. D. (1988). Properties of Thermus ruber strains isolated from Icelandic hot springs and DNA:DNA homology of Thermus ruber and Thermus aquaticus. Appl Environ Microbiol 54, 2049-2053.

Tourova, T. P., Poltoraus, A. B., Lebedeva, I. A., Tsaplina, A. I., Bogdanova, T. I. \& Karavaiko, G. I. (1994). 16S ribosomal RNA (rDNA) sequence analysis and phylogenetic position of Sulfobacillus thermosulfidooxidans. Syst Appl Microbiol 17, 509-512.

Vartanyan, N. S., Pivovarova, T. A., Tsaplina, I. A., Lysenko, A. M. \& Karavaiko, G. I. (1988). New thermoacidophilic bacterium of the genus Sulfobacillus. Microbiology (English translation of Mikrobiologiya) 57, 216-221.

Wood, A. P. \& Kelly, D. P. (1983). Autotrophic and mixotrophic growth of three thermoacidophilic iron-oxidizing bacteria. FEMS Microbiol Lett 20, 107-112.

Wood, A. P. \& Kelly, D. P. (1984). Growth and sugar metabolism of a thermoacidophilic iron-oxidizing mixotrophic bacterium. $J$ Gen Microbiol 130, 1337-1349.

Wood, A. P. \& Kelly, D. P. (1985). Autotrophic and mixotrophic growth and metabolism of some moderately thermoacidophilic iron-oxidizing bacteria. In Planetary Ecology, pp. 251-262. Edited by D. E. Caldwell, J. A. Brierley \& C. L. Brierley. New York: Van Nostrand Reinhold.

Received 15 August 1995; revised 20 November 1995; accepted 30 November 1995 